\title{
CORRELATION IS NOT CAUSATION: PROBABLE ROLE OF IMMUNIZATION WITH BACILLUS CALMETTE-GUERIN VACCINE IN ATHEROGENESIS
}

\author{
Peter I. Ghenev \\ Department of General and Clinical Pathology, Medical University, Varna, Bulgaria
}

When you light a candle, you also cast a shadow.

Ursula K. LeGuin, A Wizard of Earthsea,

Parnassus Press, 1968

In spite of the enormous volume of research in atherosclerosis, the etiological understanding of atherogenesis is still beyond compare. The Framingham Heart Study (started 1948) (1) identified the major risk factors and this concept has become an important part of the modern medical knowledge and has led to effective preventive strategies in clinical practice. But correlation is not causation. In an attempt to identify etiological factors and the immune mechanisms in atherogenesis, Georg Wick and his co-workers in a series of experiments obtained intriguing results, which confirm that atherosclerosis may be induced in rabbits by treatment with a variety of agents containing heat-shock protein of molecular weight $60 \mathrm{kD}$ (HSP60) (2-7).

Following this data, we established positive immunohistochemical expression of HSP60 in all layers of human atherosclerotic arteries - endothelial cells in both the intima and vasa vasorum, also medial smooth muscle cells, and adventitial macrophages, fibroblasts and perivascular nerve bundles (8-11) (Fig.1).

Heat-shock proteins are are highly conserved between species, and expressed during infection and inflammation. They

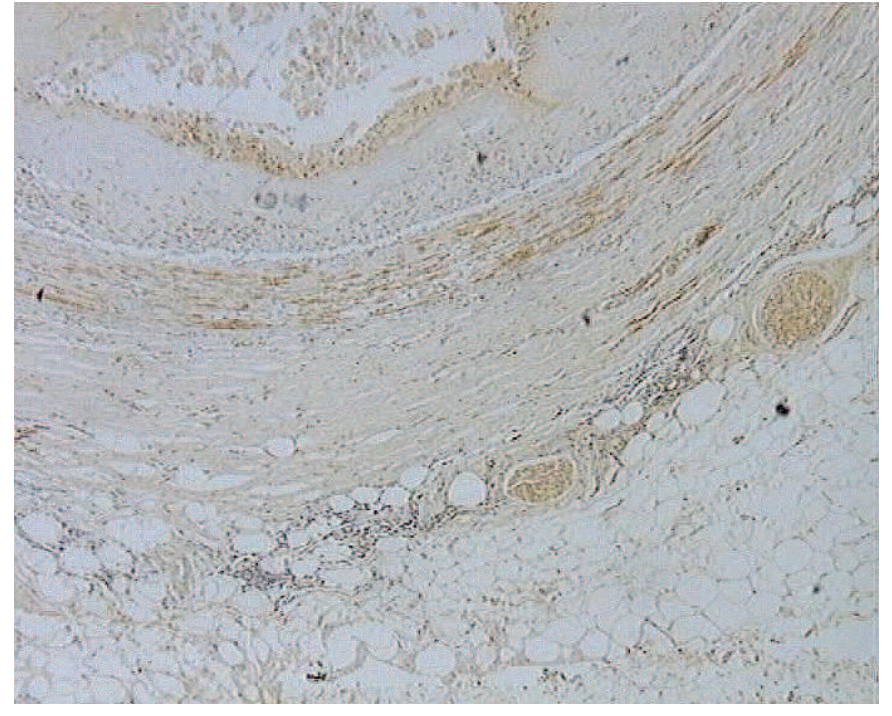

Figure 1. Immunohistochemical expression of HSP60 in the bottom part of a fibroatheroma and corresponding medial smooth muscle cells and adventitial nerve bundles in human coronary artery. Original magnification, $x 100$. 
are part of the antigenic content of infectious agents such as Chlamydia pneumoniae, Helicobacter pylori, Mycobacterium tuberculosis including bacillus Calmette-Guerin (BCG) strains $(5,6)$. Infections may contribute to atherosclerosis through direct and/or cytokine-mediated actions on vascular cells (12). These latter authors reported that the aggregate burden ("infectious burden") of these chronic infections, rather than the effects of a single organism, might contribute to atherosclerosis and its complications. Beyond the abovementioned infectious agents, a large number of infectious agents have been linked with the pathobiology of atherosclerosis; examples include Porphyromonas gingivalis, influenza A virus, herpes virus, hepatitis $\mathrm{C}$ virus, cytomegalovirus, human immunodeficiency virus (1214) and fungi (15; also 16, 17 for fungalbionic hypothesis of gout and related diseases including atherosclerosis). These can mediate the T-cell sensitization required for the production of antibodies. Likewise, mycobacterial HSP appear to be among the best candidates for adjuvants in vaccine production (19).

Dancing round these data, we are tempted to suggest that immune products (antibodies following infection and/or immunization, including BCG vaccine) may be capable of inducing atherosclerotic lesions in humans, via HSP6O mechanism. We based this proposal on:

(i) atherosclerosis is present even in children (six months after birth) (19),

(ii) every newborn receives BCG and other approximately 15 compulsory applications of immune products during the first two years of life,

(iii) all cell types involved in atherogenesis express constitutive and/or inducible HSP60 (8-11),

(iv) HSP60 is a component of vaccines and adjuvants (4),

(v) infections are the most common diseases of early childhood,

(vi) HSP60 are existing in infectious agents $(6,13,15)$,

(vii) antibodies against HSP60 circulate in the blood of patients with atherosclerosis $(5,20)$,

(viii) experimental application of HSP60 triggers atherogenesis $(3,21,22)$,

(ix) BCG immunization induces atherosclerotic lesion in rabbits $(22,23)$

(x) Mycobacteria modulate proteins of host endothelial cells (24) and macrophages (25) to enter and persist within these cells

Altogether, we suggest that $(i)$ in a manner similar to molecular Koch postulates, the atherogenic potential of HSP60/ BCG immunization should be thoroughly evaluated (see 26), and (ii) it is reasonable to try to invent immune products (vaccines) that will serve to prevent disease, without casting a shadow.

\section{References}

1. https://www.framinghamheartstudy.org/about-fhs/history. php

2. Wick G. Atherosclerosis - an autoimmune disease due to an immune reaction against heat-shock protein 60 . Herz 2000;25:87-90. PMID: 10829245

3. Xu Q, Dietrich H, Steiner HJ, Gowm AM, Schoel B, Mikuz $\mathrm{G}$, et al. Induction of atherosclerosis in normocholesterolemic rabbits by immunization with heat shock protein 65. Arterioscler Thromb 1992;12:789-799. DOI: 10.1161/01. ATV.12.7.789

4. $\mathrm{Xu} \mathrm{Q}$, Willeit J, Marosi M, Kleindienst R, Oberholenzer F, Kiechl S, et al. Association of serum antibodies to heat-shock protein 65 with carotid atherosclerosis. Lancet 1993;341:255-259. http://dx.doi.org/10.1016/01406736(93)92613-X

5. Mayr M, Kiechl S, Willeit J, Wick G, Xu Q. Infections, immunity, and atherosclerosis: associations of antibodies to Chlamydia pneumoniae, Helicobacter pylori, and cytomegalovirus with immune reactions to heat-shock protein 60 and carotid or femoral atherosclerosis. Circulation 2000;102:833-839. DOI: 10.1161/01.CIR.102.8.833

6. Grundtman S, Kreutmayer SB, Almanzar G, Wick MC, Wick G. Heat shock protein 60 and immune inflammatory responses in atherosclerosis. Arterioscler Thromb Vasc Biol 2011; 31: 960-968. DOI:10.1161/ATVBAHA.110.217877

7. Wick G, Jakic B1, Buszko M, Wick MC, Grundtman C. The role of heat shock proteins in atherosclerosis. Nat Rev Cardiol 2014;11:516-529. DOI: 10.1038/nrcardio.2014.91. Epub 2014 Jul 15.

8. Ghenev PI, Fiore M, Stankulov IS, Triaca V, Chaldakov GN, Aloe L. Role of heat shock protein 60 and nerve growth factor in human coronary atherosclerosis. In: Catravas JD, Callow AD, Ryan US, Simionescu M, editors. Vascular Endothelium - Sources and Target of Inflammatory Mediators. IOS Press, 2001; 292-293. http://dx.doi.org/10.1016/S03063623(00)00069-0

9. Ghenev P. Atherosclerotic changes in intima, media and adventitia of human aorta, coronary and cerebral arteries. Comparative morphological study. PhD Thesis, Medical University, Varna, Bulgaria. 2002

10. Ghenev P, Chaldakov G. Adventitial heat shock protein 60 in human coronary atherosclerosis. Atherosclerosis 2004;172:189-190. http://dx.doi.org/10.1016/j.atherosclerosis.2003.09.002

11. Ghenev PI, Chaldakov GN. Neural-immune links in adventitial remodeling in human coronary atherosclerosis. Circulation 1997;96:2083-2084. PMID: 9323108 
12. Tufano A, Di Capua M, Coppola A, Conca P, Cimino E, Cerbone AM, et al. The infectious burden in atherothrombosis. Semin Thromb Hemost 2012;38:515-523. DOI: 10.1055/s0032-1315759

13. Jeong E, Kim K, Kim JH, Cha GS, Kim SJ, Kang HS, et al. Porphyromonas gingivalis HSP60 peptides have distinct roles in the development of atherosclerosis. Mol Immunol 2014; 23;63:489-496. DOI: 10.1016/j.molimm.2014.10.004

14. Tuleta I, Reek D, Braun P, Bauriedel G, Nickenig G, Skowasch $\mathrm{D}$, et al. Influence of intimal Chlamydophila pneumoniae persistence on cardiovascular complications after coronary intervention. Infection 2014 Oct 26.

15. Izacc SMS, Gomez FJ, Jesuino RSA, CA, Felipe MSS, Deepe GS, et al. Molecular cloning, characterization and expression of the heat shock protein 60 gene from the human pathogenic fungus Paracoccidioides brasiliensis. Med Micol 2001; 39: 445-455. DOI:10.1080/mmy.39.5.445.455

16. Costantini AV. Fungalbionics: a new concept of the etiology of gout, hyperuricemia and their related diseases. Adv Exp Med Biol 1989; 253 A: 261- 268.

17. Constantini AV. The fungal etiology of gout and hyperuricemia: the antifungal mode of action of colchicine. Biomed Rev 1992: 1: 47-52. DOI: http://dx.doi.org/10.14748/bmr. v1.221

18. Lussow AR, Barrios C, Van Embden J, Van der Zee R, Rappuoli R, Costantino P. Mycobacterial heat-shock proteins as carrier molecules. Eur J Immunol 1991; 21: 2297-2302. DOI: 10.1002/eji.1830211002

19. Stary HC. Lipid and macrophage accumulations in arteries of children and the development of atherosclerosis. Am J Clin Nutr 2000;72(5 Suppl):1297S-1306S.
20. Pockley AG, Wu R, Lemne C, Kiessling R, de Faire U, Frostegard J. Circulating heat shock protein 60 is associated with early cardiovascular disease. Hypertension 2000;36:303-307. DOI: 10.1161/01.HYP.36.2.303

21. Mori Y, Kitamura H, Song QH, Kobayashi T, Umemura S, Cyong JC. A new murine model for atherosclerosis with inflammation in the periodontal tissue induced by immunization with heat shock protein 60. Hypertens Res 2000;23:475481. http://dx.doi.org/10.1291/hypres.23.475

22. Lamb DJ, Eales LJ, Ferns GA. Immunization with bacillus Calmette-Guerin vaccine increases aortic atherosclerosis in the cholesterol-fed rabbit. Atherosclerosis 1999;143:105-113. http://dx.doi.org/10.1016/S0021-9150(98)00284-6

23. Lamb DJ, El-Sankary W, Ferns GAA. Molecular mimicry in atherosclerosis: a role for heat shock proteins in immunisation. Atherosclerosis 2003;167:177-185. http://dx.doi. org/10.1016/S0021-9150(02)00301-5

24. Baltierra-Uribe SL, García-Vásquez Mde J, Castrejón-Jiménez NS, Estrella-Piñón MP, Luna-Herrera J, García-Pérez BE. Mycobacteria entry and trafficking into endothelial cells. Can J Microbiol. 2014;60:569-577. DOI: 10.1139/cjm2014-0087.

25. Parveen N, Varman R, Nair S, Das G, Ghosh S, Mukhopadhyay S. Endocytosis of Mycobacterium tuberculosis heat shock protein 60 is required to induce interleukin-10 production in macrophages. J Biol Chem 2013;288:24956-71. DOI: 10.1074/jbc.M113.461004.

26. Falkow S. Molecular Koch's postulates applied to bacterial pathogenicity - a personal recollection 15 years later. Nat Rev Microbiol 2004;2:67-72. PMID: 15035010 